\title{
Air Pollution Tolerance Index (APTI) and carbon sequestration of selected trees and shrubs for urban development in Akure Ondo State, Southwest Nigeria
}

\author{
A. Ibironke Okunlola, Akinola O. Adepoju and Samuel O. Agele
}

Department of Crop, Soil and Pest Management, Faculty of Agriculture, Federal University of Technology Akure, Ondo State, Nigeria

\begin{abstract}
Urban green space is a collection of trees and shrubs growing in urban area. Green plants are well known for their abilities to reduce air and noise pollution. It is important that plants used for the development of urban landscaping must be tolerant to air pollutants. There must be some criteria to select tolerant plants for urban landscaping design and for that two indices viz. Air Pollution Tolerance Index (APTI) and carbon sequestration can be a good tool. Thus this study was carried out to assess the efficiency of urban trees (Tabebuia rosea, Polyalthia longifolia, Delonix regia and Raphia farinifera) and shrubs (Ficus spp) to tolerate air pollution and potential for carbon sequestration in Akure, Ondo State, Nigeria in 2015. The sites were sampled from Akure City Major Road, from Oloko Junction to Oba-Ile. The plant species identified at the sample area were Ficus spp, Tabebuia rosea, Polyalthia longifolia, Delonix regia and Raphia farinifera. The assessment of the ascorbic acid, $\mathrm{pH}$, relative water content and total chlorophyll content of the leaves of the identified plant species was done to determine the APTI. The APTI of the plant ranged from 5.11 to 9.31 with Tabebuia rosea having the highest value which indicates it's high tolerance of air pollutants from the assessment and Raffia farinifera with the lowest value and least tolerant. The biomass of the trees species were estimated for the quantification of the amount of carbon sequestered and the absorbed $\mathrm{CO}_{2}$ in the plant. Tabebuia rosea also had the highest carbon sequestered (10,074 kg) and Delonix regia having the lowest of $4,702.50 \mathrm{~kg}$.
\end{abstract}

Keywords: Biomass and density; Carbon sequestration; Chlorophyll content; Pollution; Urban green spaces.
Received

June 8, 2016

Accepted

December 23, 2016

Released

December 31, 2016

Open Acess Full Text Article

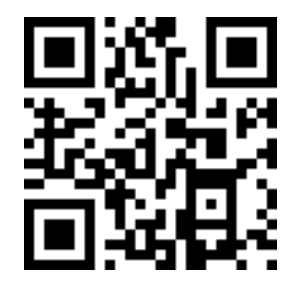

ORCIID

(ㄱ) 0000-0002-7007-1950 A. Ibironke Okunlola (ㄱ) 0000-0001-6153-9606 Akinola O. Adepoju (ㄱ) 0000-0002-3173-6745 Samuel O. Agele

\section{Introduction}

The natural environment and beautiful landscape as provided by nature has been ruthlessly exploited by man for decades. Over-exploitation of open spaces, geometric increase of automobiles and human population pressure due to rapid industrialization and random urbanization (Nowak, 2002) has further compounded the problem. Recent events has also revealed that pollution is becoming an enormous threat to human and ecosystem health and a great problem to the survival of the living biodiversity species mostly higher animals with humans as the central focus. As urban expansion continuous, environmental pollutions (air, water, soil, including sound and mental pollution) are likely to increase and new challenges might also emerge (Brown et al., 2003; Zhenga, 2013).The planting of trees and shrubs is an effective 
means of controlling pollution and improving the environment the world. There are different ways and means to mitigate the urban environmental pollution and planting of trees is an effective means and equally recognized throughout the world (Geist and Lambin 2002; Zhenga, 2013). The incessant increase of urban areas environmental pollution has made it of high importance reconsidering the whole approach of urban landscaping and its orientation in order to achieve dual effect i.e. bio-aesthetics and mitigation of pollution(Taha, 1996; Nowak et al., 2000). Environmental horticulturists have discovered a means to solve the pollution problems related to urban landscape by creating a micro-climate (Geist and Lambin, 2002).

However, more integrative studies have proven that urban trees, particularly low volatile organic compound emitting species, can be a viable strategy in reducing urban ozone levels (Taha, 1996; Nowak et al., 2000), particularly through the series of tree functions that reduce air temperature (transpiration), remove air pollutants (dry deposition to plant surfaces) (Chameides et al., 1988; Nowak 1994; Akbari and Konopacki, 2005), and reduce building energy and power plant emissions (e.g. temperature reductions; tree shade). However Nowak et al. (2000) has concluded that the physical effects of urban trees were more important than the chemical effects in terms of affecting ozone concentrations. Nationally, urban trees and shrubs (hereafter referred to collectively as "trees") offer the ability to remove significant amounts of air pollutants and consequently improve environmental quality and human health.

Trees serves as a sink for atmospheric carbon which is emitted to the atmosphere through various sources such as bush burning, greenhouse gases, fumes and smoke from houses, industries and automobile (Haase, 2013). The absent of trees will permit the escape of these gases to the space which then have the potential to deplete the ozone layer and capable of aggravating global warming (Piraino et al., 2002). As trees grow in size and shape and their biomass increases, they absorb carbon from the atmosphere and store it in the plant tissues resulting in growth of different parts (Eggleston et al., 2006). Cardille and Foley (2003) and Geist and Lambin (2002) noted one strategy for enhancing the value of the trees and shrubs is to increase the concentration of economically important, indigenous tree species by planting seeds or seedlings (enrichment planting) for future environmental sustainability (Brown et al., 2003; Montagnini and Jordan, 2005). This can be accomplished with the urban green infrastructure. Unfortunately, research efforts have not been intensified to estimate the efficiency of the urban trees and shrubs in reducing air pollution through carbon sequestration besides its aesthetic value. In Nigeria as it has been reported that carbon dioxide use by trees during photosynthesis varies from species to species (Piraino et al., 2002). Hence, this research work is set to estimate tree species efficiency, phytosociological properties and environmental functions and carbon storage in Akure, Ondo State Nigeria.

Hence forth, present study deals with the use of two indices to select most tolerant and best suited plants for development of urban green spaces. This study however, done on pilot scale but similar studies can be performed in any part of the world for selecting best plants for air pollution mitigation in urban areas. Aim of the present study was to evaluate Air Pollutant Tolerance Index (APTI) and carbon sequestration potential of selected plant species and to recommend tolerant plants for the development of urban forest.

\section{Material and methods}

\section{Study area}

Data were collected from Akure, Ondo State (longitude $50^{\circ} 20^{\prime} \mathrm{N}$ and latitude $\quad 7^{\circ} 25^{\prime} \mathrm{E}$ ) in South-Western Nigeria, Akure, from April to July 2015, has seen remarkable increase in its urbanization in recent years, and its population during the past few decade has more than tripled from 157,947, in 1990, to $\sim 500,000$, in 2006 (NDP, 2006). It is a state administrative headquarters' and transitory 
town, linked with other town. In the centre of the city, many small scales industrial plants in the town are located close to the residential areas such as liquid petroleum gas storage plants and most buildings have many ground level shops. Analysis of traffic in both centers' revealed that the most predominant mode of transport in the metropolis is through vehicular traffic private cars in particular and thus cause significant release of pollutants from burning of fossil fuel. Multi temporal remote sensing data and Geographical Information System techniques were used by Balogun et al. (2011) to detect land cover changes from 1990 to 2010.

\section{Method of assessing biomass}

There are two major method used in the carbon biomass estimation: the Destructive process and the Nondestructive process, but for the sake of this study the non-destructive method volumetric process (formula for a truncated cone and a cylinder) was used (Jandl et al., 2007). All data for this study were collected from measurements made on the identified tree species at the roads side (not more than $10 \mathrm{~m}$ to the side of the road), and shrubs planted at the middle of the lanes (not less than $0.5 \mathrm{~m}$ in height) with a Spiegel Relaskop, girth tape, and measuring tape. The botanical name or common name of every living tree and shrubs encountered at the study sites were identified. Each tree was recorded individually in the field and possible effort was made not to omit any eligible stem in a sample area except for the giving exceptions. This is because any species omitted will indicate the absence of such species in the area.

The Dbh - Diameter at breast height which is $1.3 \mathrm{~m}$ above basal level for the trees $(\mathrm{cm}), \mathrm{Db}$ - Diameter at the base $(\mathrm{cm}), \mathrm{Dm}$ - Diameter at middle $(\mathrm{cm})$, Dt Diameter at the top $(\mathrm{cm})$, and the Height (m) were all the parameters taken for volume estimation $\left(\mathrm{m}^{3}\right)$. The measurement of diameter at breast height of the tree was taken with the diameter tape, also measurement of diameter at the middle-dm and top-dt were taken with Spiegel Relaskop and the measurement of the base was done with the Girth tape for the entire trees. In measuring the total height, Spiegel Relaskop was used but at the percentage scale of the instrument. The procedure during the exercise involved taken the position at a distance from the tree which usually $10 \mathrm{~m}$ apart to be where the tree visible. After viewing through the eye window, the break button was pressed alternatively until the scale stable and the top and base reading were taken. The height was determined by Davies (2011) formula:

$$
H t=D * R t-R b / 100
$$

Where:

$\mathrm{Ht}=$ Total Height

$\mathrm{D}=$ Distance

$\mathrm{Rt}=$ Reading at the top

$\mathrm{Rb}=$ Reading the base

All data collected were analyzed using Microsoft Excel.

$$
\begin{gathered}
\text { Volume of each tree } \\
V=\pi * H t *((\mathrm{Db} 2+4(\mathrm{Dm} 2)+\mathrm{Dt} 2) / 24 \\
\text { (Hall et al }(2001)
\end{gathered}
$$

Where:

$\pi=3.142$

$\mathrm{Ht}=$ Height of the tree

$\mathrm{Db}=$ Diameter at the base

$\mathrm{Dm}=$ Diameter at the middle

$\mathrm{Dt}=$ Diameter at the top

Tree Biomass $=$ Density $\mathrm{x}$ Volume

$$
\begin{aligned}
\text { Carbon } & =50 \% \text { of Biomass } \\
\mathrm{CO}_{2} & =\text { Carbon x } 3.67
\end{aligned}
$$

where:

3.67 is a constant computed from the percentage molecular mass of $\mathrm{C}$ in $\mathrm{CO}_{2}$ and $\mathrm{CO}_{2}$ is carbon dioxide (Jandl et al., 2007).

\section{Computation of APTI}

Chlorophyll content analysis. Leaf samples will be collected from each of the encountered species at the sample location and taken to the laboratory for 
content analysis. Using $80 \%$ acetone as the reagent, the absorbance of the solution at $663 \mathrm{~mm}, 645 \mathrm{~mm}$ against the solvent $(80 \%$ acetone) blank was estimated using the spectrometer (Agbaire, 2009).

$$
\text { Total chlorophyll } \mathrm{mg} / \mathrm{g} \text { tissue }=20.2(A 645)+8.02(A 663) x \frac{V}{1000 x W}
$$

Where:

$\mathrm{A}=$ absorbance of specific wavelength

$\mathrm{V}$ = final volume of chlorophyll extract in $80 \%$ acetone extracted

$\mathrm{W}=$ fresh weight of tissue

Ascorbic acid and relative moisture content determination. Ascorbic acid was determined by using $10 \mathrm{~g}$ of the leaf samples which was transferred into a glass pestle mortar and macerated well with $4 \%$ oxalic acid. The contents were transferred to a $100 \mathrm{~mL}$ volumetric flask by filtering through a muslin cloth. The extractions were repeated with $4 \%$ oxalic acid. Titrated against $0.02 \%$ of a selective reagent 2,6 dichlorophenol indophenol dye solution taken in the burette, a permanent pale pink color was obtained. (Agbaire, 2009; and Singh and Rao 1983)

The relative water content (RWC) of the leave sample was determined using Agbaire (2009) method by placing each sample in a pre-weighed airtight vial. The vials was weighed in the lab to obtain leaf sample weight (W), after which the sample was hydrated immediately to full turgidity for 3-4 hours under normal room light and temperature. The samples were taken out water after hydration and dried of any surface moisture quickly and lightly with tissue paper and was weighed immediately to obtain fully turgid weight
(TW). Samples were then oven dried at $75^{\circ}$ $\mathrm{C}$ for $30 \mathrm{~h}$ and weighed after it has been cooled down in a desiccator to determine dry weight (DW).

NB: - The vial should be longer than the leaf sample, with its basal part to the bottom. Also the samples should reach the lab as soon as possible.

$R W C(\%)=\left[\frac{W-D W}{T W-D W} * 100\right]$

Where:

W - Sample fresh weight

TW - Sample turgid weight

DW - Sample dry weight.

For the measurement of leaf extract $\mathrm{pH}, 1 \mathrm{~g}$ of the sample was homogenized with $10 \mathrm{~mL}$ of deionized water and the $\mathrm{pH}$ of the suspension was measured with a digital $\mathrm{pH}$ meter with a glass combined electrode. The air pollution tolerance index was computed by the method suggested by Singh and Rao (1983) using the equation:

$\mathrm{APTI}=[\mathrm{A}(\mathrm{T}+\mathrm{P})+\mathrm{R}] / 10$

Where:

A = Ascorbic acid content (mg/g)

$\mathrm{T}=$ Total chlorophyll (mg/g)

$\mathrm{P}=\mathrm{pH}$ of leaf extract

$\mathrm{R}=$ Relative water content of leaf

(\%).

Table 1. Categorization of plants according to its Air Pollutant Toleration Index values (APTI).

\begin{tabular}{ll}
\hline Index value & Category \\
\hline $4.0-5.0$ & Sensitive \\
$5.0-6.0$ & Intermediate \\
$6.0-7.0$ & Tolerant \\
$>7.0$ & Highly tolerant \\
\hline
\end{tabular}




\section{Statistical analysis}

The analysis of LULCC (Land Use and Land Cover Change) was predicated basically on the usage of remote sensing and GIS techniques. Also it was used for the classification of imagery, image processing and enhancement. ArcView was also used in displaying, subsequent processing and enhancement of the image (Balogun et al., 2011). After obtaining the variables for volume estimation, the biomass and APTI calculations were determined electronically using Microsoft excel and SPSS 16.0.

\section{Results}

\section{Tree status and growth variables (carbon and carbon dioxide)}

The essential important of trees and shrubs in the urban environment in modifying the air quality by removal of certain air pollutants has been revealed by the results. It also indicated the potential environmental impact of the urban green space on the city's air quality. The Figure 1 below shows the decreasing trend of urban trees and shrubs and the rapid demand for land for buildings and other social use due to increase population and urbanization.

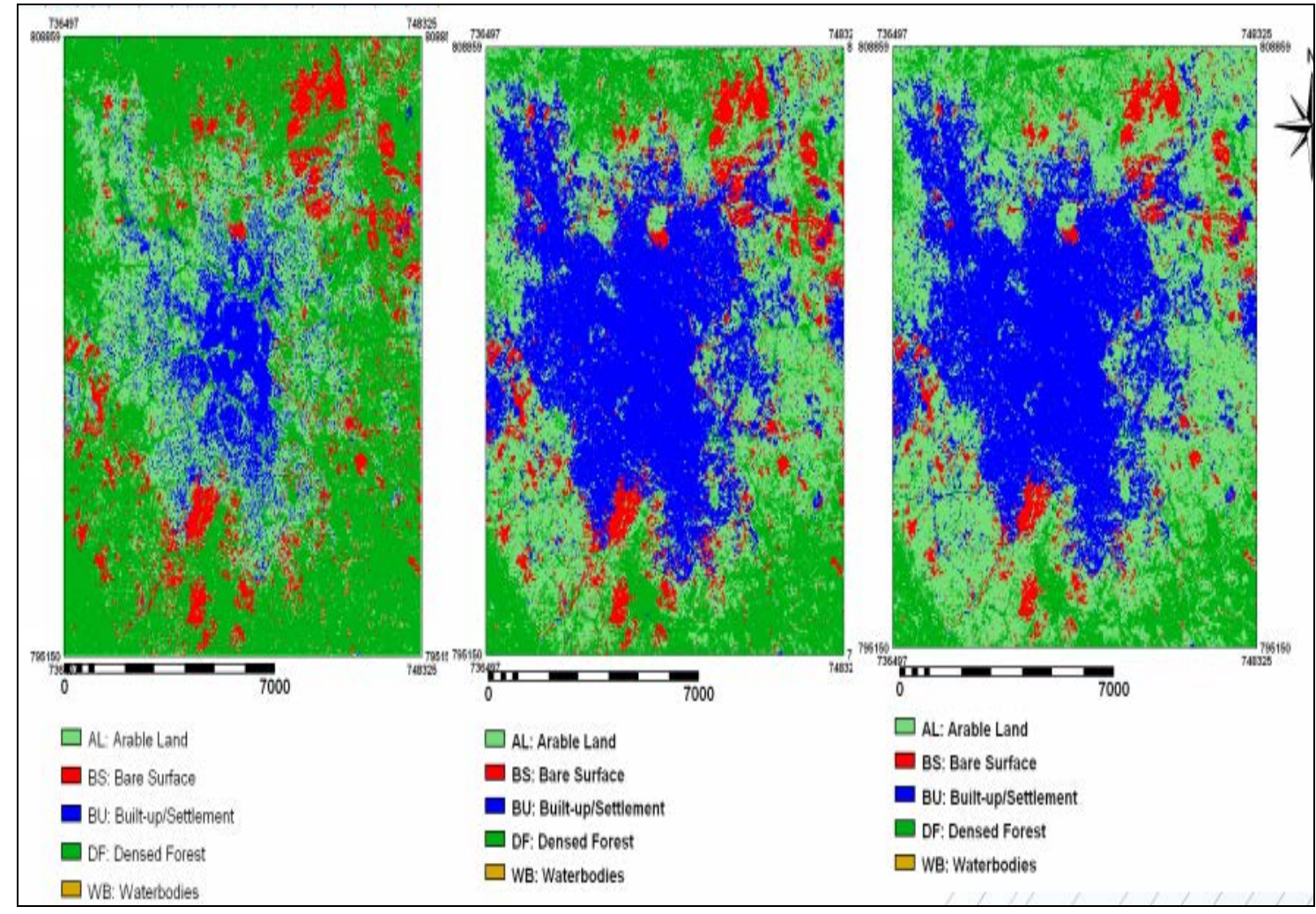

a)

b)

c)

Figure 1 (a, b and c): Land use and Land cover map area of Akure in 1986, 2002 and 2007 respectively, showing decreasing level of urban trees and forest degradation (Authorized: Balogun et al., 2011)

\section{Carbon sequestration potentials}

The list of the tree and shrub species encountered in the sample location is presented in Table 2 . The Table indicates that ficus spp (yellow ficus) of the family Moraceae has the highest frequency (711) followed by Tabebuia rosea of Bignoniaceae (233) while the rest has lower number of occurrence as presented in the table below. The result of the estimated value of the tree growth variables according to species in the study areas is presented in Table 2. The Table revealed that Ficus spp has the highest number frequency which indicates its abundance in the sample area and Raffia farinifera has the lowest frequency. The result also showed that the 
amount of biomass and carbon stock of each individual tree species have been able to sequestrate. Ficus spp in the middle demarcation of the road has total carbon stock of $632.42 \mathrm{~kg}$ and the one on the road side has $1,120.79 \mathrm{~kg}$ and a total of 1,753.21 $\mathrm{kg}$. It revealed also that Tabebuia rosea has the highest amount of carbon stock of $2,744.99 \mathrm{~kg}$ though relatively lower in frequency than Ficus spp and followed by Raphia farinifera carbon stock of 2,195.96 $\mathrm{kg}$ though it has the lowest frequency in its appearance in the sample location. The
Table also showed the volume, biomass, tree wood density, carbon stock and the amount of $\mathrm{CO}_{2}$ (carbon dioxide) sequestrated overtime. The results showed that Tabebuia rosea also has the highest amount $\mathrm{CO}_{2}$ been absorbed in the value of $10,074.09 \mathrm{~kg}$, followed by Raphia farinifera with a $\mathrm{CO}_{2}$ stock of 8,059.16 kg and Delonix regia having the lowest amount of $\mathrm{CO}_{2}$ stock with a value of $4.702 .50 \mathrm{~kg}$.

Table 2. Summary of phytosociological results and tree growth variable.

\begin{tabular}{llcccrc}
\hline & Plant species & FREQ & Density kg/m & Total Carbon (kg) & Total CO2 (kg) & ATPI \\
\hline 1 & Ficus spp & 711 & 390 & $1,753.21$ & $6,434.28$ & 6.31 \\
2 & Tabebuia rosea & 233 & 540 & $2,944.99$ & $10,074.09$ & 9.31 \\
3 & Delonix regia & 209 & 800 & $1,281.34$ & $4,702.50$ & 7.57 \\
4 & Polyalthia longifolia & 12 & 510 & $1,761.94$ & $6,466.33$ & 6.74 \\
5 & Raphia farinifera & 11 & 640 & $2,195.96$ & $8,059.16$ & 5.11 \\
\hline & Total & 1,176 & - & $9,937.44$ & $35,736.36$ & -
\end{tabular}

Freq. $=$ frequency; APTI $=$ Air Pollutant Tolerance Index.

The results of tree growth variables also shows that the higher the volume of the plant species, the higher the amount of the biomass and consequently the higher the carbon stock which is also an indication of increasing level of $\mathrm{CO}_{2}$ absorption. The effect of individual tree density is constant for all species, with Ficus spp having a wood density of 0.39, Tabebuia rosea with 0.54 , and Delonix regia 0.80 , also with Polyalthia longifolia having 0.51 and finally Raphia farinifera with 0.64 all in $\mathrm{g} / \mathrm{cm}^{3}$, i.e. $390,540,800,510,640 \mathrm{in} \mathrm{kg} / \mathrm{m}^{3}$, respectively. The estimation of the volume of plant species was a function of the plant growth variables which are: diameter at the top, diameter at the middle, diameter at the base, and height. The individual values of these growth parameters are factors which influence the amount of volume estimation, biomass, and carbon stock. The higher the value of these growth variables the higher the estimated volume, which leads to increase in the $\mathrm{CO}_{2}$, estimated.

The frequency of the individual encountered plant species in the sample location is computed against the $\mathrm{CO}_{2}$ absorbed as presented in Figure 2 based on the growth parameters. As shown in Figure 2 the plants with highest bars on the graph showed high amount of $\mathrm{CO}_{2}$ absorption and the lowest bars also shows minimum level of $\mathrm{CO}_{2}$ absorption. This result indicates that the higher the values of these growth parameters the higher the amount the carbon stock and the $\mathrm{CO}_{2}$ absorbed. The total percentage of the carbon stock of each| plant species of the total amount is shown with Tabebuia rosea having the highest percentage of $28 \%$ and Ficus spp (middle road demarcation) has the lowest carbon stock of $12 \%$ despite its relative abundance in the location. 
Figure 2: Percentage carbon stock of each individual species in the overall carbon stock on the location

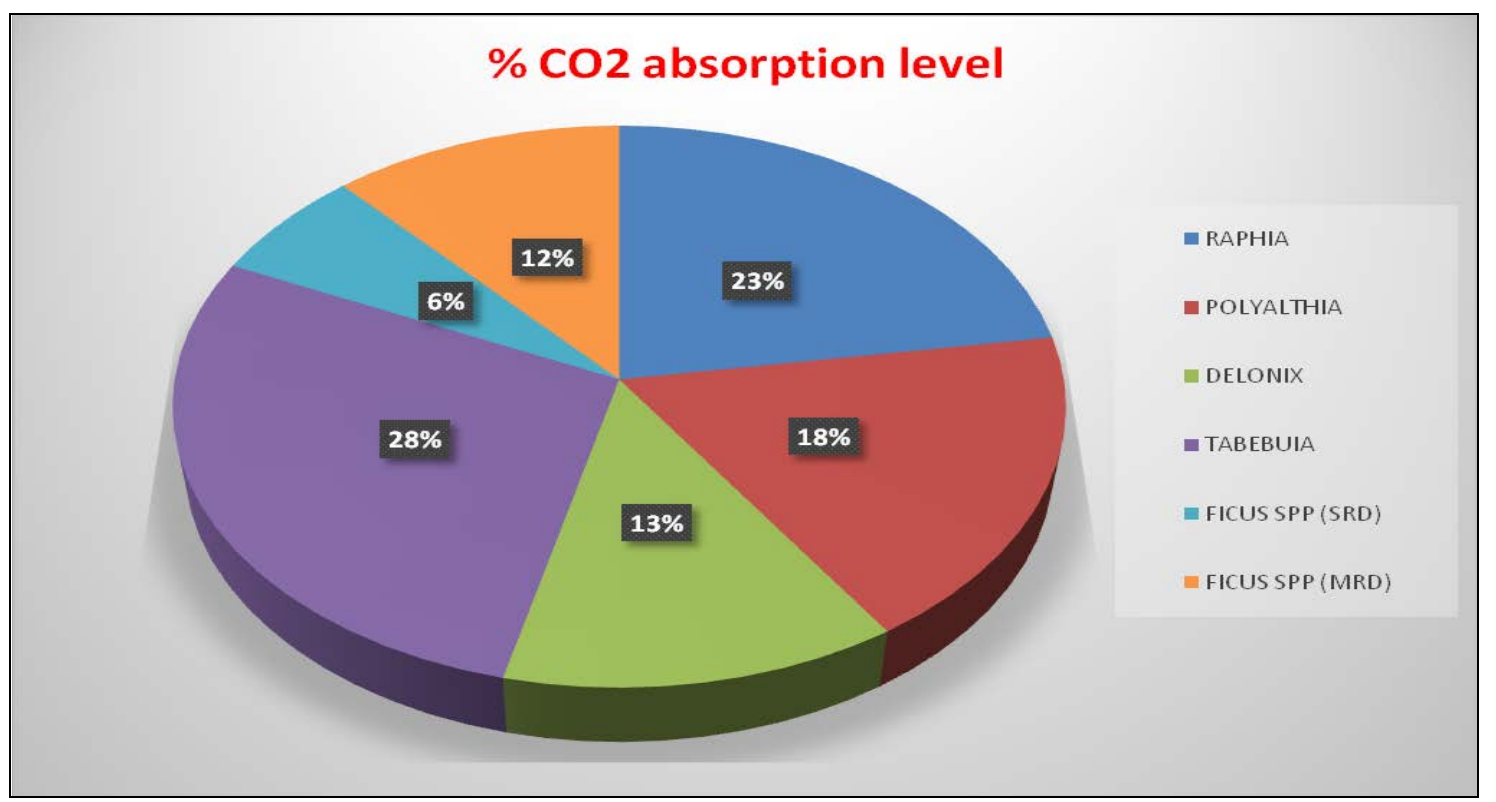

Ficus spp = (SRD: side road demarcation; MRD: middle road demarcation).

\section{APTI analysis}

The leaf sampled of the identified plant species in the sampled area was analyzed for the biochemical parameters and which was used to calculate the APTI, and the results are shown in Table 3. From the result it was evident that the plants showed varied degree of tolerance index to air pollution. The APTI of the plant ranged from 5.11 to 9.31 with Tabebuia rosea having the highest value and Raffia farinifera with the lowest value. The table also shows the air pollution tolerance index of some selected ornamental shrubs. In which the result ranged from 5.78 to 6.31 with Ficus spp having the highest APTI value and Duranta erecta with the lowest. The Table 4 showed that air pollution tolerance index categorization from sensitive to highly tolerant. In the grouping, 2 plant species are highly tolerant and 2 also are tolerant and the rest species are intermediate.

Table 3: Analyzed biochemical parameters values of selected plants along the three selected sampling location in study area.

\begin{tabular}{|l|c|c|c|c|c|c|}
\hline Plant species & TC $\mathbf{~ m g / g}$ & $\mathbf{A ~ m g / g}$ & $\mathbf{p H}$ & RWC (\%) & APTI & Category \\
\hline Ficus spp & $1.49 \pm 0.032$ & $0.45 \pm 0.058$ & 7.37 & $58.69 \pm 2.12$ & 6.31 & Tolerant \\
\hline Tabebuia rosea & $3.68 \pm 0.018$ & $2.32 \pm 0.036$ & 5.36 & $71.13 \pm 1.76$ & 9.31 & Highly Tolerant \\
\hline Delonix regia & $1.87 \pm 0.047$ & $2.39 \pm 0.074$ & 6.15 & $54.50 \pm 1.14$ & 7.57 & Highly Tolerant \\
\hline Polyalthia longifolia & $1.15 \pm 0.071$ & $0.60 \pm 0.091$ & 5.99 & $62.54 \pm 1.32$ & 6.74 & Tolerant \\
\hline Raphia farinifera & $1.81 \pm 0.085$ & $1.08 \pm 0.027$ & 5.84 & $42.57 \pm 1.23$ & 5.11 & Intermediate \\
\hline Croton variegatum & $2.04 \pm 0.096$ & $0.42 \pm 0.011$ & 6.96 & $55.49 \pm 1.68$ & 5.94 & Intermediate \\
\hline Duranta erecta & $1.32 \pm 0.091$ & $0.68 \pm 0.045$ & 5.72 & $52.63 \pm 1.05$ & 5.78 & Intermediate \\
\hline Duranta golden & $1.34 \pm 0.082$ & $0.55 \pm 0.058$ & 5.60 & $50.07 \pm 2.08$ & 5.81 & Intermediate \\
\hline
\end{tabular}

$\mathrm{T}=$ Total chlorophyll (mg $\mathrm{g}^{-1}$ of dry weight), $\mathrm{T}(\mathrm{c})=$ Total chlorophyll at control site, $\mathrm{T}(\mathrm{c})=$ Total chlorophyll at the study site; $\mathrm{A}=$ ascorbic acid (mg g ${ }^{-1}$ of fresh weight; $\mathrm{P}=$ leaf extract; $\mathrm{pH} ; \mathrm{R}=$ relative water content (\%). 
Table 4: Arrangement of plant species in decreasing order of APTI.

\begin{tabular}{lclc}
\hline Tree species & APTI & Shrubs & APTI \\
\hline Tabebuia rosea & 9.31 & Ficus spp & 6.31 \\
Delonix regia & 7.57 & Croton variegatum & 5.94 \\
Polyalthia longifolia & 6.74 & Duranta golden & 5.81 \\
Raphia farinifera & 5.11 & Duranta erecta & 5.78 \\
\hline
\end{tabular}

\section{Discussion}

In the developing countries, Nigeria in particular urban ecosystem has been under the threat of increase urbanization due to increasing population and rural urban shift over years, which has led to the loss of tree biodiversity, reduction in green infrastructures and increasing global temperature (global warming) (Nowak et al., 2002). Trees and shrubs in public green spaces which are mainly devoted to outdoor recreational use played important role in air pollutant removal, which accounted for more than half of the total value of air pollutant removal (Brown, 1997). As revealed by the results of this study, urban trees contributed $2.5 \%$ to local carbon sequestration (IEA - Statistics International Energy Agency electronics files on $\mathrm{CO}_{2}$ emissions from various carbon sources) to the total value of carbon dioxide pollutant removal. The average range of $\mathrm{CO}_{2}$ concentration and emission in Akure is about 1500-2000t, $\mathrm{CO}_{2}$ absorption in urban areas played pivotal roles in cleaning the air. The results confirmed the leading role of urban trees in ushering more environmental benefits than other any other pollution removal method (Nowak et al., 2002). The study further indicated the importance of greenery design and quality in pollution abatement, by maintaining large and more continuous tree cover in urban setups (Nowak, 2006). Moreover, as many of the identified trees are still young, their environmental advantages and benefits will appreciate significantly overtime when the trees attain their final dimensions and size permissible by site conditions (Miller et al., 2015; Nowak, 2010 and Beckett et al., 1998).

Some species have been identified to be more pollution-tolerant and more capable of extracting pollutants from the atmosphere. These species should be preferentially planted where appropriate to enhance the air pollutant removal function (Brown, 1997). However, such information in the study area is sparingly available. Further research on tree species in Nigeria could inform future species selection to enhance air pollutant removal as well as reduction in potential volatile organic emission. The size, growth form and health condition of individual plants could affect the amount of pollutant removal per tree. Trees with a large leaf surface area can remove 60 to 70 times more pollutants a year than small ones (Nowak 2010). Also, broad leaf species could remove more pollutants than conifer or palm species, which usually have lower specific leaf surface areas (Shen et al., 2003).

Moreover, as air pollutant removal occurs principally during in-leaf time, evergreen species that grow throughout the year could contribute more than deciduous ones, and the difference is particularly pronounced in dry season which has higher pollutant emissions in Akure and many Nigerian cities. Furthermore, the stomata condition of plants could alter the activity of air pollutant absorption. Therefore, it is important to sustain healthy and functional trees within urban green spaces. Urban air quality could be improved through planting appropriately selected species adjacent to pollution sources according to their resistance to pollutants and the local concentration of main pollutants (Nowak, 2006). Another factor that determines the canopy cover area is the vegetation structure and which also determines the efficiency of air pollutant removal by urban trees. An appropriate biomass structure should be considered in the layout and design of urban green spaces in addition to aesthetic and functional considerations (Haase, 2013). For a given site, the 
availability of planting space and the designed function will define the possible configuration and placement of urban green infrastructure. Maximum benefits could be achieved by 2 to 3 rows of trees with a relatively high planting density and adequate ventilation in a confined space. The quality of green space management might also have a bearing on air pollutant removal. Sound, effective and intensive management and maintenance, including timely pruning, watering on dry days, and pest monitoring and control, could effectively improve plant health and thus their intensities of photosynthesis and respiration which could increase pollutant absorption (Haase, 2013). Besides the ecosystem services of air pollutant removal, urban trees could also contribute to the improvement of local air quality by improving microclimate. By shading buildings and evapotranspiration, local air temperature could drop. Thus vegetation could reduce cooling demand and avoid emissions of air pollutants from power plants, such as $\mathrm{SO}_{2}$ and $\mathrm{NO}_{2}$ (Akbari, 2002).

\section{Conclusion}

The results of this study indicate the potential of the urban green infrastructure (trees and shrubs) for biodiversity conservation, carbon sequestration, environment protection, aesthetics (urban beautification), air pollutant removal, and reduction of urban heat temperature (urban heat island). The results also reveal that degraded areas could be managed in a sustainable manner through green infrastructure programs and development. This is shown by the highest number of plant species, species density and diversity, aesthetic value and perception, growth pattern and more carbon sequestration potential obtained for the sample area. Through pollution removal and other tree functions (e.g. air temperature reductions), urban trees can help improve air quality via air pollutant removal in cities, and consequently help improve human health. While the existing percent air quality improvements due to pollution removal by urban trees are modest, they can be improved by increasing urban tree canopy cover.

\section{Conflicts of interest}

Authors declare that they have no conflict of interests.

\section{References}

Agbaire, P. O. Air pollution tolerance indices (ATPI) of some plants around Erhoike-Kokori oil exploration site of Delta State, Nigeria. International Journal of Physical Sciences, v. 4, no. 6, p. 366-368, 2009. Available from: $<$ http://www.academicjournals.org/journal/IJPS/ article-full-text-pdf/58B05DE19073>. Accessed on: Feb. 23, 2016.

Akbari, $\mathrm{H}$. Shade trees reduce building energy use and $\mathrm{CO}_{2}$ emissions from power plants. Environmental Pollution, v. 116, suppl., p. S119-S126, 2002. http://dx.doi.org/10.1016/S0269-7491(01)00264-0

Akbari, H. S., Konopacki, S. Calculating energy-saving potentials of heat-island reduction strategies. Energy Policy, v. 33, no. 6, p. 721-756, 2005. http://dx.doi.org/10.1016/j.enpol.2003.10.001

Balogun, I. A.; Z.; Balogun, A. A. Z.; Adeyewa, $D$. Landuse - landcover change detection and associated climatic responses in Akure, Nigeria. Boulder, Colorado, USA: ISP-NCAR Summer Colloquium on African Weather and Climate, 2011. Available from: $<$ https://ral.ucar.edu/csap/events/ISP/posters/bal ogun_Ifeoluwa.pdf $>$. Accessed on: Feb. 23, 2016.

Beckett, K. P.; Freer-Smith, P.; Taylor, G. Urban woodlands: their role in reducing the effects of particulate pollution. Environmental Pollution, v. 99, p. 347-360, 1998.

Brown, N.; Jennings, S.; Clements, T. The ecology, silviculture and biogeography of mahogany (Swietenia macrophylla): a critical review of the evidence. Perspectives in Plant Ecology, Evolution and Systematics, v. 6, p. 37-49, 2003.

Brown, S. Estimating biomass and biomass change of tropical forests: a primer. Rome: Food and Agriculture Organisation, 1997. (UN FAO Forestry paper). 
Cardille, J. A.; Foley, J. A. Agricultural landuse change in Brazilian Amazonia between 1980 and 1995: evidence from integrated satellite and census data. Remote Sensing of Environment, v. 87, p. 551-562, 2003.

Chameides, W. L.; Fehsenfeld, F.; Rodgers, M. O.; Cardelino, C.; Matinez, J.; Parrish, D.; Lonnemans, W.; Lawson, D. R.; Rasmussen, R. A.; Zimmerman, P.; Greenberg, J.; Middleton, P.; Wang, T. Ozone precursor relationships in the ambient atmosphere. J. Geophys. Res., v. 97, no. D5, p. 6037-6055, 1992. http://dx.doi.org/10.1029/91JD03014

Davies, Z. E. Mapping an urban ecosystem service. quantifying above-ground carbon storage at a city-wide scale. Journal of Applied Ecology, v. 48, p. 1125-1134, 2011.

Eggleston, H. S.; Buendia, L.; Miwa, K.; Ngara, T.; Tanabe, K. (Eds.). 2006 IPCC Guidelines for National Greenhouse Gas Inventories. Hayama, Japan: Institute for Global Environmental Strategies, IPCC Intergovernmental Panel on Climate Change, 2006. (v. 4; Agriculture, Forestry and Other Land Use). Available from: <http://www.ipccnggip.iges.or.jp/public/2006gl/vol4.html>.

Accessed on: Feb. 23, 2016.

Geist, H. J.; Lambin, E. Proximate causes and underlying driving forces of tropical deforestation. Bioscience, v. 52, no. 2, p.143150, 2002. http://dx.doi.org/10.1641/ 00063568(2002)052[0143:PCAUDF]2.0.CO;2

Haase, D. L. Diversity of ecosystem services provisioning in European cities. Proc. 6th Annual International ESP Conference 2013, v. 34, p.125-453, 2013.

Jandl, R.; Vesterdal, L.; Olsson, M.; Bens, O.; Badeck, F.; Roc, J. Carbon sequestration and forest management. CAB Reviews: Perspectives in Agriculture, Veterinary Science, Nutrition and Natural Resources, v. 2, no. 17, 16 p., 2007.

McPherson, G.; Geiger, J. Environmental benefits of trees in urban areas. Journal of the International Society of Arboriculture, p. 1214, 2005.

Miller, R. W.; Hauer, R. J.; Werner, L. P. Urban forestry: planning and managing urban greenspaces. 3. ed. Long Grove, IL: Waveland, 2015.

Montagnini, F.; Jordan, C. F. (Eds.). Tropical forest ecology: the basis for conservation and management. New York: Springer, 2005. http://dx.doi.org/10.1007/b138811
NDP - Nigeria Data Portal. Nigeria Census. $2006 . \quad$ Available from: $<$ http://nigeria.opendataforafrica.org/xspplpb/ni geria-census>. Accessed on: Feb. 23, 2016.

Nowak, D. J. Air pollution removal by Chicago's urban forest. In: McPherson, E. G.; Nowak, D. J.; Rowntree, R. A. (Eds.). Chicago's urban forest ecosystem: results of the Chicago Urban Forest Climate Project. Radnor, PA: USDA Forest Service, Northeastern Forest Experimental Station, 1994. p. 63-81.

Nowak, D. J.; Civerolo, K. L.; Rao, S. T.; Sistla, G.; Luley, C. J.; Crane, D. E. A modeling study of the impact of urban trees on ozone. Atmospheric Environment, v. 34, p. 16011613, 2000. http://dx.doi.org/10.1016/S13522310(99)00394-5

Nowak, D. J.; Crane, D. E. Carbon storage and sequestration by urban trees in the USA. Environmental Pollution, v. 116, no. 3, p. 381389, 2002. http://dx.doi.org/10.1016/S02697491(01)00214-7

Nowak, D. J.; Crane, D. E.; Stevens, J. C. Air pollution removal by urban trees and shrubs in the United States. Urban Forestry \& Urban Greening, v. 4, no. 3/4, p. 115-123, 2006. http://dx.doi.org/10.1016/j.ufug.2006.01.007

Nowak, D. J.; Stein, S. M.; Randler, P. B.; Greenfield, E. J.; Comas, S. J.; Carr, M. A.; Alig, R. J. Sustaining America's urban trees and forests: a forests on the edge report. Newtown Square, PA: U.S. Department of Agriculture, Forest Service, Northern Research Station, 2010. 27 p. (Gen. Tech. Rep. NRS-62).

Nowak, D. J.; Stevens, J. C.; Susan, M. S.; Christopher, J. L. Effects of urban tree management and species selection on atmospheric carbon dioxide. Journal of Arboriculture, v. 28, no. 3, p. 113-122, 2002. Available from: $\quad<$ http://joa.isaarbor.com/request.asp?JournalID=1\&ArticleID =37\& Type=2>. Accessed on: Feb. 23, 2016.

Piraino, S.; Fanelli, G.; Boero, F. Variability of species' roles in marine communities: change of paradigms for conservation priorities. Mar. Biol., v. 140, no. 5, p. 1067-1074, 2002. http://dx.doi.org/10.1007/s00227-001-0769-2

Shen, S.; Li, W.; Fan, Y.; Pan, H. Evaluation of three-dimensional green biomass of green space of Qingxiushan in Nanning. Journal of Central South Forestry University, v. 23, no. 5, p. 88-91, 2003. 
Singh, S. K.; Rao, D. N. Evaluation of plants for their tolerance to air pollution. Proceedings of the Symposium on Air Pollution Control, p. 218-224, 1983.

Taha, H. Modeling impacts of increased urban vegetation on ozone air quality in the South Coast Air Basin. Atmospheric Environment, v. 30, no. 20, p. 3423-3430, 1996. http://dx.doi.org/10.1016/1352-2310(96)00035-0

Zhenga, D. D. Assessing net carbon sequestration on urban and community forests of northern. Urban Forestry \& Urban Greening, v. 12, no. 1, p. 61-68, 2013.

License information: This is an open-access article distributed under the terms of the Creative Commons Attribution License, which permits unrestricted use, distribution, and reproduction in any medium, provided the original work is properly cited.

Braz. J. Biol. Sci., 2016, v. 3, no. 6, p. 395-405. 